\title{
Effect of Foliarly Applied Spirotetramat on Reproduction of Heterodera avenae on Wheat Roots
}

R. W. Smiley, Columbia Basin Agricultural Research Center, Oregon State University, Pendleton 97801; J. M. Marshall, Cereals Pathology and Agronomy Program, University of Idaho, Idaho Falls 83402; and G. P. Yan, Columbia Basin Agricultural Research Center, Oregon State University, Pendleton 97801

\begin{abstract}
Smiley, R. W., Marshall, J. M., and Yan, G. P. 2011. Effect of foliarly applied spirotetramat on reproduction of Heterodera avenae on wheat roots. Plant Dis. 95:983-989.

The cereal cyst nematode, Heterodera avenae, has the potential to reduce yields of cereal crops in the Pacific Northwest. Spirotetramat (Movento) is a foliar-applied insecticide with ambimobile translocation that reduces fecundity of sucking insects which feed on roots as well as foliage. Spirotetramat $(88 \mathrm{~g} / \mathrm{ha})$ was applied to foliage during 2010 in two wheat fields infested by $H$. avenae near St. Anthony, ID and Palouse, WA. In Idaho, two applications at 2-week intervals during late spring to plants already exhibiting swollen white females reduced the postharvest density of $H$. avenae eggs plus juveniles by $35 \%(P=0.03)$ compared to the nontreated control. In Washington, a single application

before white females became apparent reduced the nematode density by $78 \%(P=0.01)$. Grain yields and test weights were not significantly affected by application of spirotetramat at either location. In addition, symptomatic plants from the Idaho field were transplanted into greenhouse pots and treated with spirotetramat. One application $(110 \mathrm{~g} / \mathrm{ha})$ reduced numbers of eggs plus juveniles/plant by $78 \%(P=0.02)$. Spirotetramat effectively reduced $H$. avenae populations and warrants further evaluation as a substitute for crop rotations or long fallow periods that reduce nematode population densities in infested fields.
\end{abstract}

The cereal cyst nematode, Heterodera avenae Woll., is widely distributed and economically important in most temperate regions of the world $(1,15,16,21)$. In North America, $H$. avenae was first reported during 1935 in Ontario, Canada (5), and during 1974 in the United States in western Oregon (9). This species is now known to occur in localized regions of at least seven western U.S. states, including the Pacific Northwest (PNW) states of Idaho, Oregon, and Washington (18). In Oregon, $H$. avenae has reduced yields of spring and winter wheat (Triticum aestivum L.) by as much as $39 \%$ in field trials and has occasionally destroyed commercial crops of spring wheat $(20,23)$. The value of reduced wheat yields due to this pathogen in the PNW was estimated at $\$ 3.4$ million annually (18).

Wheat is a principal crop in the PNW and is often produced as a 2-year monoculture of winter wheat (10 months) and fallow (14 months), or as a 3-year rotation of winter wheat, spring wheat or barley, and either a pulse crop or fallow. Management strategies for controlling $H$. avenae include genetic resistance, crop rotation, long fallow periods, and chemical and biological control (2). Wheat, barley (Hordeum vulgare), and oat (Avena sativa) genotypes with resistance to the $H$. avenae pathotype in the PNW have been described (25). An effective resistance gene (Crel) has been crossed into PNW-adapted wheat cultivars, but genetic resistance is not yet available in commercial cultivars. Rotation of cereals with multiple years of nonhost crops (families other than Poaceae) or fallow effectively reduce the $H$. avenae population density in soil $(20,24)$, but in the semi-arid PNW, rotations with a low frequency of cereals are generally less profitable than rotations containing a high frequency of cereals, including the winter wheat/fallow monoculture. No nematicides in the United States are registered for controlling damage by $H$.

Corresponding author: R. W. Smiley,

E-mail: richard.smiley@ oregonstate.edu

Accepted for publication 26 March 2011.

doi:10.1094/PDIS-01-11-0017

(C) 2011 The American Phytopathological Society avenae, and biological control products are not known to be effective for controlling $H$. avenae.

Wheat and barley plants with roots damaged by $H$. avenae appear initially as pale green seedlings that lack vigor and are often severely stunted in growth (24). Plants with visual damage often occur in patches but may also occur over entire fields, particularly under monocultures of susceptible cereals and when combined with inadequate plant nutrition or other stress. Roots invaded by $H$. avenae branch excessively at locations where juveniles have invaded, resulting in a bushy or knotted appearance (24). Root symptoms often do not become recognizable until one to three months after planting, depending upon weather conditions and spring or winter wheat growth habit (21).

This nematode completes one reproductive generation per crop season (1). Freshly hatched second-stage juveniles penetrate epidermal cells behind the root cap and move intracellularly to the growth zone. A rapid succession of molts leads to differentiation of juveniles into males and females. Males remain vermiform and migratory, and exit the root within about 3 weeks. Females induce the formation of a specialized feeding cell (syncytium) from which they feed until mature, in about 6 to 9 weeks. The syncytium is located in the endodermis or pericycle, near phloem cells in the root. Females remain sedentary and embedded in the root, where they are fertilized by multiple males and 100 to 600 eggs are formed. The swollen female body is most easily observed at the flowering time of wheat. It protrudes from the root surface, glistens when wet, and is white to gray in color. The presence of one or more white swollen female bodies ( 0.5 to $2 \mathrm{~mm}$ diameter) at the point of abnormal root proliferation is diagnostic (24), but their presence among knotted roots is often obscured by adhering soil.

Upon death of host roots, the female body wall dies and hardens into a resistant dark-brown cyst (24) that typically dislodges into the soil as the wheat root system decomposes. Eggs inside the cyst may remain viable for several years. Emergence of infective second-stage juveniles through the fenestrae of the brown cyst is triggered by complex interactions among soil temperature, soil moisture, and exudates from host roots (1). Peak numbers of infective juveniles in soil generally coincide with the traditional wheat sowing and seedling growth stages in each geographic region. Egg hatching is favored by cool temperatures $\left(2\right.$ to $\left.10^{\circ} \mathrm{C}\right)$, and develop- 
ment of the nematode is favored by dry conditions during growth of the host (1). The hatching rate from an individual cyst may vary from 40 to $90 \%$ each year, with hatching extending to as long as 6 years when soil is continuously cool and dry (1).

It is difficult to directly relate initial populations with reduction in grain yield because the damage threshold varies with soil type, climate, and cultivar, and with nematode virulence and ecotype characteristics. Moreover, fields infested by H. avenae in the PNW are often also infested by other economically important plant-parasitic nematode species, of which the most important are the rootlesion nematodes Pratylenchus neglectus and P. thornei (19), and the stunt nematode Geocenamus brevidens (syn. Merlinius brevidens) (22).

Spirotetramat is a new ketoenol insecticide with both phloem and xylem mobility (ambimobile) in many crop species, including wheat $(14,17,26)$. Once inside the leaf, spirotetramat is hydrolyzed to spirotetramat-enol, the form in which the compound enters the xylem and phloem and is translocated throughout the plant. The compound is a Group 23 lipid biosynthesis inhibitor that reduces fecundity (number of eggs deposited) and fertility (viability of eggs produced) when ingested orally by immature life stages of sucking insects such as aphids, psyllids, scales, leafminers, thrips, mealybugs, and whiteflies. Incomplete edysis (shedding of the cuticle during molting) has also been observed in aphid populations, leading to immobility and subsequent death of affected individuals. Spirotetramat is the first broad-spectrum insecticide that exhibits basipetal translocation from foliage into roots. It has very short residual activity in soil, with more than $90 \%$ dissipation in 1 to 4 days, but has a residual activity of two or more weeks within plants. Spirotetramat is registered for controlling many sucking insect pests of citrus, grapes, pome fruit, stone fruit, tree nuts, hop, tree plantations, and vegetable crops in the United States (Movento label, Bayer CropScience, 30 June 2008). Application rates of 70 to $88 \mathrm{~g}$ a.i./ha and 88 to $175 \mathrm{~g}$ a.i./ha are labeled for use on vegetables and tree and vine crops, respectively. In field crops, spirotetramat has also been shown to be effective for controlling damage from stinkbugs (Dichelops melacanthus) that invade the lower stems of soybean (Glycine max) and wheat in Brazil (11). This insecticide has also protected roots of lettuce (Lactuca sativa) and endive (Cichorium endivia) against attack by the Woolly root aphid (Pemphigus bursarius) for periods up to 6 weeks and 3 months, respectively (3).

In what appears to have been the first experiments to determine effects of spirotetramat on plant-parasitic nematodes, McKenry et al. $(12,13)$ demonstrated that applications to foliage reduced the number of Pratylenchus vulnus in rhizosphere soil around roots of walnut (Juglans spp.) by $50 \%$ over a 6-month period. These authors also found that application of spirotetramat to grape (Vitis spp.) leaves reduced the number of Xiphinema americanum by up to $70 \%$ when roots were sampled 18 days after treatment, reduced the number of Meloidogyne spp. as much as $50 \%$ for up to 3 months, and reduced the number of Tylenchulus semipenetrans for 6 weeks.

Spirotetramat does not appear to have been evaluated for its capacity to suppress population densities of nematodes that injure wheat. Sedentary females of $H$. avenae ingest nutrients from syncytia located near the stele, making it possible that basipetal translocation of spirotetramat could impede reproduction of $H$. avenae in a manner similar to that described for root-feeding aphids $(3,10,14)$ and for several plant-parasitic nematode species that attack roots of trees and vines $(12,13)$. The objectives of this research were therefore to determine the potential for spirotetramat to suppress the population density of $H$. avenae and to improve the yield of wheat.

\section{Materials and Methods}

Spirotetramat (Movento, $240 \mathrm{~g}$ a.i./liter) was applied to the foliage of spring wheat on two fields known to be infested by $H$. avenae. A greenhouse trial was also conducted using plants naturally infested in the field and then transplanted into greenhouse pots before being treated.
Field trials. Experiments were conducted during 2010 in two commercial fields of nonirrigated spring wheat located near St. Anthony, ID and Palouse, WA. All crop management practices were performed by the growers, including tillage, fertilizer application, planting, and weed control.

Description of field sites. The Idaho site was in Fremont County, at coordinates $43^{\circ} 55.203^{\prime} \mathrm{N}$ and $-111^{\circ} 38.321^{\prime} \mathrm{W}$, and at $1,509 \mathrm{~m}$ elevation. The site receives $352 \mathrm{~mm}$ of mean annual precipitation and has a continental, semiarid climate. Mean monthly temperatures in January and August are -7 and $18^{\circ} \mathrm{C}$, respectively. The soil was a St. Anthony gravelly sandy loam, a very deep, well drained loamy-skeletal, mixed, superactive, frigid Calcic Pachic Haploxerolls. The field was managed as a 2-year rotation of spring wheat and cultivated fallow. Spring wheat cultivar Alturas was planted on 26 March 2010 following summer fallow during 2009 and a crop of hard red spring wheat harvested September 2008.

The Washington site was in Whitman County, at coordinates $46^{\circ} 52.808^{\prime} \mathrm{N}$ and $-117^{\circ} 14.511^{\prime} \mathrm{W}$, and at $716 \mathrm{~m}$ elevation. The site receives $509 \mathrm{~mm}$ of mean annual precipitation and has a Mediterranean, semiarid climate. Mean monthly temperatures in January and August are -1 and $18^{\circ} \mathrm{C}$, respectively. The soil was a Latah silt loam, a deep, somewhat poorly drained fine, mixed, superactive, mesic Xeric Argiabolls. The field was managed as a 3-year rotation of winter wheat, spring wheat, and a spring pulse crop such as field pea or chickpea. Spring wheat cultivar Nick was planted on 16 April 2010 following a crop of winter wheat cultivar Cashup harvested during August 2009.

Temperature and rainfall during the experimental periods were obtained from records at the airport nearest each site. The Rexburg Madison County Airport was located $17 \mathrm{~km}$ from the Idaho site, and the Pullman-Moscow Regional Airport was located $18 \mathrm{~km}$ from the Washington site. Temperature degree-days following the planting of each wheat crop were calculated using the "Degree-day Calculator - enter your own thresholds" at http://uspest.org/cgibin/ddmodel.pl; retrieved 21 March 2011). Inputs included the selection of the nearest airport, the base temperature for the calculation, and the date on which the wheat was planted. A base temperature of $0^{\circ} \mathrm{C}$ was used to estimate growth and development of wheat (4) and a base temperature of $8^{\circ} \mathrm{C}$ to estimate the development of $H$. avenae (6).

Experimental design. Experiments at each farm consisted of three treatments replicated eight times in a randomized complete block design. The plot size was $1.8 \times 19.1 \mathrm{~m}$. Experiments were established on 19 May in Washington and 18 June in Idaho. The three treatments consisted of a nontreated control (spirotetramat was not applied), spirotetramat applied to foliage once, and spirotetramat applied twice (Idaho) or three times (Washington). Application dates and plant growth stages are shown in Table 1. Prior to application, as required by the manufacturer (Movento label, Bayer CropScience), the commercial formulation of spirotetramat was tank-mixed with a spreading and penetrating adjuvant to maximize leaf uptake and systemicity of the product marketed in the United States. We used a tank mix consisting of $0.25 \%(\mathrm{vol} / \mathrm{vol})$ MSO, a proprietary blend of methylated oils and nonionic surfactants (Helena Chemical Company). Spirotetramat was applied at a rate of $88 \mathrm{~g} /$ ha with a $\mathrm{CO}_{2}$-pressurized hand-held sprayer with four Tee Jet XR8002 flat fan nozzles spaced at 46-cm intervals and operated at an application volume of 133 liters/ha and a pressure of $207 \mathrm{kPa}$.

Nematode population density. A single bulked preplant soil sample was collected from each experimental area immediately before each experiment was initiated. Samples consisted of a composite of approximately 30 soil cores $(2.54 \mathrm{~cm}$ diameter $\times 30 \mathrm{~cm}$ depth) collected from the 0.045 -ha experimental area, representing a sampling intensity of 667 subsamples/ha. Samples were submitted to Western Laboratories, Parma, ID for extraction and enumeration of all plant-parasitic nematode genera. The laboratory uses a modified Oosterbrink elutriator method (8) to extract and collect vermiform and encysted life stages on separate sieves. Cysts were broken mechanically to extract eggs and larvae, and the suspension was 
added to the suspension of vermiform life stages. The suspension was then concentrated through multiple sequences of centrifugation and density flotation using an $\mathrm{MgSO}_{4}$ solution. All plant-parasitic nematodes were enumerated at the genus level by Western Laboratories.

Postharvest densities of $H$. avenae were determined in each plot at each location. Samples were collected directly below the wheat row. In Idaho, 10 soil cores $(2.54 \mathrm{~cm}$ diameter $\times 30 \mathrm{~cm}$ depth $)$ were collected from each of the 24 plots on 20 September, for a total of 24 samples collected 12 weeks after the final spirotetramat application. In Washington, the dry soil was too dense to collect postharvest samples using a core sampler. Samples were therefore taken on 27 August ( 9 weeks after the last spray application) by collecting from each plot four shovel slices about $2.5 \mathrm{~cm}$ thick, $10 \mathrm{~cm}$ wide, and $10 \mathrm{~cm}$ in depth. $H$. avenae cysts were extracted and numbers of eggs plus juveniles, from cysts, were quantified by Western Laboratories. Other nematode species were not enumerated in the postharvest samples because their population densities were low when the experiments were initiated at each location.

Nematode identification. Heterodera and Pratylenchus species extracted from preharvest samples at each field location were identified morphologically and molecularly.

For Heterodera spp., key morphological features examined under a compound light microscope included cyst color, underbridge in the vulval cone, semifenestrae shape, and development of bullae $(7,28)$. DNA was extracted from 3 to 5 cysts from each sample and examined using the polymerase chain reaction-restriction fragment length polymorphism (PCR-RFLP) technique described by Yan and Smiley $(27,28)$. Briefly, DNA was extracted using a Bio 101 FastDNA Kit. The internal transcribed spacer (ITS) region of rDNA was amplified using primers 18S (5'-TTGATTACGTCC CTGCCCTTT- $\left.3^{\prime}\right)$ and 26S (5'-TTTCACTCGCCGTTACTAAGG$\left.3^{\prime}\right)$. PCR reactions $(20 \mu \mathrm{l})$ consisted of $3 \mu \mathrm{l}$ DNA, $1 \times$ PCR buffer with $1.5 \mathrm{mM} \mathrm{MgCl} 2,0.2 \mathrm{mM}$ dNTPs, $0.5 \mu \mathrm{M}$ of each primer, 0.5 $\mathrm{mM} \mathrm{MgCl}$, and 1.25 units of Taq polymerase. PCR amplifications were conducted using a program as follows: $94^{\circ} \mathrm{C}$ for $2 \mathrm{~min} ; 40$ cycles of $94^{\circ} \mathrm{C}$ for $1 \mathrm{~min}, 60^{\circ} \mathrm{C}$ for $50 \mathrm{~s}$, and $72^{\circ} \mathrm{C}$ for $1 \mathrm{~min}$; and $72^{\circ} \mathrm{C}$ for $7 \mathrm{~min}$. The PCR products were digested with three restriction endonucleases: TaqI, HinfI, and RsaI. The species of Heterodera was determined by comparing the restriction pattern with those of control species in agarose gels by electrophoresis.

Identification of Pratylenchus species was made by examining DNA of nematodes extracted from soil using the protocol described by Yan et al. (29). Twenty root-lesion nematodes consisting of a mixture of juveniles and adult females were hand-picked, placed into $40 \mu \mathrm{l}$ of sterilized nanopure water on a glass slide, and cut into pieces under a stereomicroscope. Twenty microliters of suspension containing nematode pieces were pipetted into a $0.5-\mathrm{ml}$ sterile tube with $16 \mu \mathrm{l}$ of worm lysis buffer $(500 \mathrm{mM} \mathrm{KCl}, 100 \mathrm{mM}$
Tris-Cl, $\mathrm{pH} 8.3,15 \mathrm{mM} \mathrm{MgCl} 2,10 \mathrm{mM}$ DTT, 4.5\% Tween 20, and $0.1 \%$ gelatin). The tube was frozen at $-20^{\circ} \mathrm{C}$ for $30 \mathrm{~min}$ and then quickly thawed. Four microliters of $600 \mu \mathrm{g} / \mathrm{ml}$ proteinase $\mathrm{K}$ was added to the tube. The tube was incubated at $65^{\circ} \mathrm{C}$ for $1 \mathrm{~h}$ and then kept at $95^{\circ} \mathrm{C}$ for $10 \mathrm{~min}$ to inactivate the proteinase $\mathrm{K}$. The supernatant of nematode lysis mix was then used as the DNA template. Species-specific PCR was performed on the nematode DNA using the forward primer PNEG-F1 (5'-CGCAATGAAAGTGAACAA TGTC- $3^{\prime}$ ) and reverse primer D3B5 (5'-AGTTCACCATCTTTC GGGTC-3') to identify P. neglectus, and the forward primer PTHO (5'-GAAAGTGAAGGTATCCCTCG-3') and the reverse primer D3B (5'-TCGGAAGGAACCAGCTACTA-3') to identify P. thornei (29). PCR reactions $(25 \mu \mathrm{l})$ consisted of $5 \mu \mathrm{l}$ DNA, 0.75 units of Taq polymerase, $200 \mu \mathrm{M}$ dNTPs, $0.5 \mu \mathrm{M}$ of each primer, $1 \times$ PCR buffer with $1.5 \mathrm{mM} \mathrm{MgCl}_{2}$, and $1 \times$ Cresol Red in $20 \%$ glycerol. PCR amplification was performed using the following program: $95^{\circ} \mathrm{C}$ for $3 \mathrm{~min} ; 35$ cycles of $95^{\circ} \mathrm{C}$ for $30 \mathrm{~s}, 60^{\circ} \mathrm{C}$ (PNEG$\mathrm{F} 1 / \mathrm{D} 3 \mathrm{~B} 5)$ or $62^{\circ} \mathrm{C}(\mathrm{PTHO} / \mathrm{D} 3 \mathrm{~B})$ for $30 \mathrm{~s}$, and $72^{\circ} \mathrm{C}$ for $30 \mathrm{~s}$; and $72^{\circ} \mathrm{C}$ for $7 \mathrm{~min}$. PCR products were separated in $2 \%$ standard agarose gels stained with ethidium bromide. Molecular size was estimated by a 100-bp DNA ladder. The band pattern of the test sample was compared to that of DNA from pure nematode cultures (positive controls). Sterilized nanopure water without DNA template served as a negative control.

Crop development and grain yield. Stand uniformity and appearance were evaluated visually at each spirotetramat application date. Characteristics observed included the color and height of foliage, and the uniformity of head height. Since no differences were apparent, physical measurement of these parameters was not performed. Approximately 10 plants were also removed from control treatments and adjacent borders on each application date to determine if root knotting symptoms or swollen white females of $H$. avenae were apparent on roots. Grain yield in Washington was determined on August 27 (154 days after planting and 100 and 66 days after the first and third application, respectively) by harvesting entire plots using a Hege plot combine (Wintersteiger Inc.). Entire plots in Idaho were harvested on 9 September (153 days after planting and 93 and 78 days after the first and second application, respectively) using a Wintersteiger plot combine (Wintersteiger Inc.). Grain weight and test weight were determined manually for each sample from Washington and were measured and recorded using on-combine monitoring equipment in Idaho.

Greenhouse trial. Nontreated wheat plants were collected from the Idaho field immediately before the field experiment was initiated. Plants with minimal soil adhering to roots were transplanted individually into pots containing $300 \mathrm{~g}$ of heat-sterilized Walla Walla silt loam (coarse-silty, mixed, superactive, mesic Typic Haploxerolls). Plants were watered and incubated for 7 days at $14^{\circ} \mathrm{C}$ (approximating the temperature in the field at the time of collec-

Table 1. Dates and plant growth characteristics during 2010 when spirotetramat was applied to wheat in fields in Idaho and Washington, and to wheat plants collected from the naturally infested field in Idaho on 18 June and transplanted into the greenhouse

\begin{tabular}{|c|c|c|c|c|c|c|c|}
\hline \multirow[b]{2}{*}{ Location } & \multirow[b]{2}{*}{ Application $^{x}$} & \multicolumn{2}{|c|}{ Date (2010) } & \multicolumn{2}{|c|}{ Degree-days $^{w}$} & \multirow[b]{2}{*}{ Zadoks growth scale ${ }^{\mathrm{z}}$} & \multirow[b]{2}{*}{ Morphological growth stage } \\
\hline & & Calendar & DAPy & $0^{\circ} \mathrm{C}$ base & $8^{\circ} \mathrm{C}$ base & & \\
\hline St. Anthony, ID & $\begin{array}{l}1 \\
2\end{array}$ & $\begin{array}{l}18 \text { June } \\
\text { 30 June }\end{array}$ & $\begin{array}{l}63 \\
75\end{array}$ & $\begin{array}{l}1,287 \\
1,674\end{array}$ & $\begin{array}{l}448 \\
669\end{array}$ & $\begin{array}{l}40 \\
59\end{array}$ & $\begin{array}{l}\text { Flag leaf emerging } \\
\text { Heads fully emerged }\end{array}$ \\
\hline Palouse, WA & $\begin{array}{l}1 \\
2 \\
3\end{array}$ & $\begin{array}{l}19 \text { May } \\
8 \text { June } \\
22 \text { June }\end{array}$ & $\begin{array}{l}54 \\
74 \\
88\end{array}$ & $\begin{array}{r}618 \\
1,001 \\
1,318\end{array}$ & $\begin{array}{l}215 \\
345 \\
471\end{array}$ & $\begin{array}{l}13 \\
16 \\
40\end{array}$ & $\begin{array}{l}3 \text { leaves fully extended } \\
6 \text { leaves fully extended } \\
\text { Flag leaf extended, booting }\end{array}$ \\
\hline Greenhouse & $\begin{array}{l}1 \\
2\end{array}$ & $\begin{array}{l}24 \text { June } \\
5 \text { July }\end{array}$ & $\begin{array}{l}69 \\
80\end{array}$ & $\begin{array}{l}1,469 \\
1,781\end{array}$ & $\begin{array}{l}532 \\
676\end{array}$ & $\begin{array}{l}40 \\
59\end{array}$ & $\begin{array}{l}\text { Flag leaf emerging } \\
\text { Heads fully emerged }\end{array}$ \\
\hline
\end{tabular}

${ }^{w}$ Temperature degree-days following the planting of each wheat crop. Wheat growth responds to a $0^{\circ} \mathrm{C}$ base temperature (4), and development of $H e t e r o d e r a$ spp. responds to a $8^{\circ} \mathrm{C}$ base temperature (6). Values shown in the table were from the degree-day calculator at http://uspest.org/cgi-bin/ddmodel.pl, which used heat units measured from daily records at the nearby weather stations at Rexburg Madison County Airport in Idaho and at Pullman-Moscow Regional Airport in Washington. Heat units in the greenhouse experiment were calculated by adding to the initial values calculated for the field an estimate of heat units accumulated in the greenhouse.

${ }^{\mathrm{x}}$ Spirotetramat applications were at the rate of $88 \mathrm{~g} / \mathrm{ha}$ in field trials, or at a rate equivalent to $110 \mathrm{~g} / \mathrm{ha}$ in the greenhouse trial.

y Days after planting.

${ }^{\mathrm{z}}$ Zadoks wheat plant growth scale (30). 
tion) to allow plant recovery from transplant stress. Fifteen plants of uniform size were then moved into a greenhouse maintained at $22 \pm 5^{\circ} \mathrm{C}$. The trial consisted of three treatments replicated five times in a randomized complete block design. Treatments included a nontreated control and spirotetramat applied at a rate equivalent to $110 \mathrm{~g} / \mathrm{ha}$ applied either once or twice (Table 1). This rate, $25 \%$ higher than that applied in the field, was applied to examine the maximum potential effect during the first year in which spirotetramat was being evaluated for its potential to control $H$. avenae on wheat. Plants were moved outdoors briefly during the foliar application process, using the same equipment used for applications in the field. Heat units (growing degree-days) in the greenhouse experiment were calculated as described for the field experiments, using a sum of initial values accumulated in the field and, after being transplanted, heat units monitored inside the greenhouse. White and brown cysts of $H$. avenae were extracted on 12 August (49 and 38 days after the first and second application, respectively) by wet sieving cysts from roots plus soil and also by manually removing cysts embedded in roots using a microscope (25). All cysts were counted and up to five representative cysts from each greenhouse pot were crushed and the eggs plus juveniles were counted. Cysts on treated plants often contained empty eggs (without an embryo), and these eggs were excluded from the counts of potentially viable eggs reported.

Statistical analysis. Nematode population data were transformed using $\ln (x+1)$ to normalize nematode counts prior to statistical analysis. All data were analyzed individually using univariate analysis of variance (ANOVA) with number of spirotetramat treatments as treatment and replicates as blocks. ANOVA was performed using CoStat Statistical Software version (Co-Stat v. 6.400, CoHort Software). When treatment means were significant at $P<$ 0.05 , means were separated using the Tukey's honestly significant difference (HSD) test. After analysis, the transformed means for nematode data were back-transformed for purposes of reporting.

\section{Results}

Field trials. When the trial was initiated in Idaho, the site was found to be infested with a high average density of $H$. avenae (15,312 eggs + juveniles $/ \mathrm{kg}$ of soil) and low densities of Pratylenchus neglectus $(308 / \mathrm{kg})$ and a Tylenchorynchus sp. (176/kg). In Washington, the same groups of nematodes were present: 11,011 $H$. avenae eggs plus juveniles $/ \mathrm{kg}, 715$ P. neglectus $/ \mathrm{kg}$, and 33 Tylenchorynchus $\mathrm{sp} . / \mathrm{kg}$.

In Idaho, roots exhibited knotting symptoms and $H$. avenae swollen white females when the first spray was applied. The first and second applications of spirotetramat were made when 1,287 and 1,674 growing degree-days $\left(0^{\circ} \mathrm{C}\right.$ base $)$ had accumulated after planting (Table 1). Flag leaves were emerging at the time of the first application, and heads had fully emerged when the second application was made. If an $8^{\circ} \mathrm{C}$ base was used for the heat unit calculations, these applications were made at 448 and 669 growing degree-days, respectively. Only $1 \mathrm{~mm}$ of precipitation occurred during the 12 days following the first application of spirotetramat, and $10 \mathrm{~mm}$ occurred on days 10 and 11 after the second application.

In Washington, root knotting was not apparent at the time the experiment was initiated but was apparent during the second application. Swollen white females were first observed on roots when the third application was made. The first, second, and third applications of spirotetramat were made when $618,1,001$, and 1,318 growing degree-days $\left(0^{\circ} \mathrm{C}\right.$ base) had accumulated after planting (Table 1). Plant growth at the three applications was at the three-leaf, six-leaf, and booting stage, respectively. If an $8^{\circ} \mathrm{C}$ base was used for the heat unit calculations, these applications were made at 215,345 , and 471 growing degree-days, respectively. Rain was frequent but of low intensity after the first application: $10 \mathrm{~mm}$ occurred on days 2 and 3 following application, $12 \mathrm{~mm}$ on days 8 and 9 , and $42 \mathrm{~mm}$ on days 12 through 19. Rain also occurred following the second application ( $3 \mathrm{~mm}$ several hours after the spray was applied, $21 \mathrm{~mm}$ on days 1 through 3 , and $10 \mathrm{~mm}$ on days 12 and 13) and the third application ( $2 \mathrm{~mm}$ on day 2 , and $3 \mathrm{~mm}$ on days 10 and 11).

Application of spirotetramat to wheat foliage reduced the postharvest density of $H$. avenae in soil at both locations (Table 2). In Idaho, two applications of spirotetramat significantly $(P<0.05)$ reduced the $H$. avenae density by $35 \%$ compared to the nontreated control. A single application reduced the density by $28 \%$ but was not statistically different than the control or the two applications. In Washington, where spirotetramat was applied earlier in the growing season (Table 1 ), the postharvest $H$. avenae density was significantly $(P<0.05)$ less in both insecticide treatments compared to the nontreated control. A single application of spirotetramat reduced nematode density by $78 \%$, and three applications suppressed the density by $90 \%$.

No visual differences in foliar growth or color, or in head height, were observed among treatments at either location. Grain yield and grain test weight did not differ significantly among treatments (Table 2). A single application of spirotetramat appeared to cause slightly lower yields (2 and 2.3\%) and test weights (0 and $0.4 \%$ ) in Idaho and Washington, respectively. Compared to a single application, the reductions appeared to be greater from multiple applications: 9.3 and $3.2 \%$ for yields, and 0.8 and $0.5 \%$ for test weights in Idaho and Washington, respectively.

Table 2. Grain yield, test weight, and postharvest density of Heterodera avenae in soil samples collected below wheat rows in nontreated plots and in plots treated with spirotetramat in commercial wheat fields in spring near St. Anthony, ID and Palouse, WA during 2010

\begin{tabular}{|c|c|c|c|c|c|}
\hline \multirow[b]{2}{*}{ Location } & \multirow[b]{2}{*}{ Application $^{\mathrm{y}}$} & \multicolumn{2}{|c|}{ Heterodera avena $^{\mathrm{x}}$} & \multirow[b]{2}{*}{ Grain yield (kg/ha) } & \multirow[b]{2}{*}{ Test weight (g/liter) } \\
\hline & & Density $^{z}$ & $\%$ of control & & \\
\hline \multirow[t]{6}{*}{ Idaho } & 0 & $25,297 \mathrm{a}$ & & 1,575 & 603 \\
\hline & 1 & $18,096 \mathrm{ab}$ & 72 & 1,544 & 603 \\
\hline & 2 & $16,548 \mathrm{~b}$ & 65 & 1,428 & 598 \\
\hline & $\operatorname{HSD}_{(0.05)}$ & 7,408 & & ns & $\mathrm{ns}$ \\
\hline & $P>F$ & 0.03 & & 0.36 & 0.92 \\
\hline & $\mathrm{CV}(\%)$ & 2.9 & & 13.8 & 4.3 \\
\hline \multirow[t]{6}{*}{ Washington } & 0 & $9,581 \mathrm{a}$ & $\ldots$ & 5,573 & 777 \\
\hline & 1 & $2,099 \mathrm{~b}$ & 22 & 5,447 & 774 \\
\hline & 3 & $973 \mathrm{~b}$ & 10 & 5,394 & 773 \\
\hline & $\operatorname{HSD}_{(0.05)}$ & 1,209 & & ns & $\mathrm{ns}$ \\
\hline & $P>F$ & 0.01 & & 0.38 & 0.57 \\
\hline & $\mathrm{CV}(\%)$ & 15.7 & & 4.7 & 1.0 \\
\hline
\end{tabular}

${ }^{\mathrm{x}}$ Spirotetramat applications were either not applied or were applied once (18 June) or twice (18 June and 30 June) in Idaho, or were applied once (19 May) or three times (19 May, 8 June, and 22 June) in Washington. Each application was at the rate of $88 \mathrm{~g} / \mathrm{ha}$.

y Postharvest soil samples were collected on 20 September in Idaho and on 27 August in Washington. Sampling depth was $30 \mathrm{~cm}$ in Idaho and $10 \mathrm{~cm}$ in Washington. Nematode data are back-transformed means derived from analysis of natural log-transformed data. For individual locations, column numbers followed by the same letter are not significantly different $(\alpha=0.05)$ as determined by Tukey's honestly significant difference (HSD) test.

${ }^{\mathrm{z}} \mathrm{H}$. avenae eggs plus juveniles $/ \mathrm{kg}$ of soil, derived from extraction and crushing of cysts. 
Greenhouse trial. When the plants were removed from the field, roots of all plants exhibited extensive knotting symptoms characteristic of those caused by $H$. avenae. Swollen white females were also evident. The first and second applications of spirotetramat were made when 1,469 and 1,781 growing degree-days $\left(0^{\circ} \mathrm{C}\right.$ base) had accumulated after planting (Table 1$)$. If an $8^{\circ} \mathrm{C}$ base was used for these calculations, these applications were made at 532 and 676 growing degree-days, respectively. Spirotetramat treatments did not lead to any visual differences in plant growth or development but significantly $(P<0.05)$ suppressed production of $H$. avenae cysts per plant as much as $81 \%$ and numbers of eggs plus juveniles per plant as much as $89 \%$ (Table 3). For each of these parameters, there was no statistically significant difference for effects of a single versus multiple applications. Although spirotetramat reduced numbers of potentially viable eggs plus juveniles in individual cysts by $39 \%$, this reduction did not differ significantly $(P$ $=0.56$ ) from the nontreated control. Counts of eggs plus juveniles included mostly eggs and very few $(<1 \%)$ or no juveniles.

\section{Discussion}

Basipetal translocation of spirotetramat applied to wheat foliage reduced the reproductive capacity of $H$. avenae on wheat roots. To our knowledge, this is the first report of a foliarly applied compound capable of reducing the density of $H$. avenae and thereby reducing the level of risk to subsequent plantings of susceptible cereal crops. We have previously demonstrated that grain yield is negatively associated with the preplant density of $H$. avenae $(20,23)$. In the current experiments, the density of $H$. avenae in soil was reduced as effectively by application of spirotetramat to foliage of a susceptible wheat cultivar as could be expected from rotations to resistant cultivars, nonhost crops, or fallow $(2,16,20)$. This effect is similar to that described for Woolly root aphid on lettuce and endive (3), and for several species of plant-parasitic nematodes on roots of walnut trees and grapes $(12,13)$. Application of spirotetramat may be particularly useful for wheat monocultures or rotations that do not allow adequate time for the $H$. avenae population to become sufficiently diminished between host crops.

In eastern Oregon, juveniles of $H$. avenae emerge from cysts starting in late February, and numbers of infective juveniles in soil become greater over a period of 30 to 60 days during March and April (24). Spring cereals in infested areas of eastern Oregon are typically planted during early April. Infection of newly formed roots is anticipated to occur over a period of at least 3 to 5 weeks after juveniles first begin to emerge from cysts and seek roots of a host. At locations where our experiments were performed in eastern Washington and eastern Idaho, the typical planting dates for spring wheat occur later than in eastern Oregon due to a cooler climate (Idaho) or a greater spring-time rainfall (Washington). As such, the greatest populations of infective juveniles are likely to occur in soil during late March to early May at those locations.

Application of spirotetramat reduced the $H$. avenae density to values below the presumed threshold value of 5,000 eggs plus juveniles/kg of soil (24) in Washington but not in Idaho. The greater magnitude of reduction in $H$. avenae density in Washington (90\%) than in Idaho (35\%) was presumed to reflect the different timing of applications relative to invasion and development of gravid females in the root systems. Hajihasani et al. (6) described the life cycle of the cereal cyst nematode $H$. filipjevi and related the life stages to degree-days using a base temperature of $8^{\circ} \mathrm{C}$. They reported that $H$. filipjevi required between 200 and 250 degree-days from the time of juvenile invasion into the root until swollen white females were visible, between 250 and 300 degree-days until egg laying commenced, and between 325 and 390 degree-days until eggs contained embryos, e.g., eggs were viable. Our first application of spirotetramat was made at 448 and 215 degree-days $\left(8^{\circ} \mathrm{C}\right.$ base) in Idaho and Washington, respectively. When the first application of spirotetramat was made in these field trials, the swollen white females of $H$. avenae were already present on roots in Idaho but not in Washington. $H$. avenae and $H$. filipjevi are closely related and occur as mixed populations in many regions and even within individual fields $(15,27)$. If the degree-days required for development of $H$. avenae are approximately the same as for $H$. filipjevi, as appears likely, viable eggs would have already been formed in the earliest-forming cysts at the time of our first spirotetramat application in Idaho. Likewise, at the time of our first application in Washington, white females would have been in the process of being formed but egg laying would not have commenced. These differences in estimates of $H$. avenae development, based on degree-days following the wheat planting date, could explain the different magnitude of reproductive suppression measured in our trials.

In these experiments, the final densities of $H$. avenae in treated plots, compared to the nontreated controls, did not differ significantly between a single or multiple applications in Idaho and Washington. We conclude that a single application of spirotetramat can suppress the fecundity of $H$. avenae on wheat and that the application is likely to be most effective when seedlings have at least three leaves fully extended, quantified as Zadoks growth scale $13+(30)$, or an accumulation of at least 600 growing degree-days $\left(0^{\circ} \mathrm{C}\right.$ base $)$ after the seed was planted.

The initial density of more than 15,000 eggs plus juveniles $/ \mathrm{kg}$ of soil in the Idaho field during mid-June closely approximated the density measured in treated plots after harvest. This contrasted with an amplified postharvest density of $H$. avenae in nontreated control plots. It is therefore possible that suppression of $H$. avenae fecundity was as effective in Idaho as in Washington, but could not be adequately measured because of the unknown proportions of $H$. avenae eggs plus juveniles counted in our postharvest samples that were enclosed within old cysts formed in previous wheat crops, as compared to eggs plus juveniles in cysts newly formed on the current wheat crop.

On plants of equal age and origin, spirotetramat appeared to have had a stronger suppressive effect on $H$. avenae reproduction when applied in the greenhouse trial than applied in the field trial

Table 3. Population densities of Heterodera avenae in greenhouse pots after naturally infected spring wheat plants were collected from a field near St. Anthony, ID, transplanted into greenhouse pots, and then incubated without treatment or after one or two treatments with spirotetramat

\begin{tabular}{|c|c|c|c|c|c|c|}
\hline \multirow[b]{2}{*}{ Application $^{\mathrm{z}}$} & \multicolumn{2}{|c|}{ Cysts/plant ${ }^{y}$} & \multicolumn{2}{|c|}{ Eggs + juveniles/cyst } & \multicolumn{2}{|c|}{ Eggs + juveniles/plant } \\
\hline & Density & $\%$ of control & Density & $\%$ of control & Density & $\%$ of control \\
\hline 0 & $47 \mathrm{a}$ & $\ldots$ & 317 & $\ldots$ & $14,725 \mathrm{a}$ & $\ldots$ \\
\hline 1 & $17 \mathrm{~b}$ & 36 & 194 & 61 & $3,274 \mathrm{~b}$ & 22 \\
\hline 2 & $9 \mathrm{~b}$ & 19 & 193 & 61 & $1,586 \mathrm{~b}$ & 11 \\
\hline $\operatorname{HSD}_{(0.05)}$ & 10 & & ns & & 2,326 & \\
\hline$P>\mathrm{F}$ & $<0.01$ & & 0.56 & & 0.02 & \\
\hline CV (\%) & 13.2 & & 10.8 & & 8.9 & \\
\hline
\end{tabular}

${ }^{y}$ Number of $H$. avenae extracted from roots and soils in each greenhouse pot, expressed as number of white plus brown cysts/plant, mean number of eggs plus juveniles in an individual cyst, and mean number of eggs plus juveniles produced on each plant. Data are back-transformed means derived from analysis of natural log-transformed data. Column numbers followed by the same letter are not significantly different $(\alpha=0.05)$ as determined by Tukey's honestly significant difference (HSD) test.

${ }^{\mathrm{z}}$ Spirotetramat applications either were not applied or were applied once (24 June) or twice (24 June and 5 July). Each application was at a rate equivalent to $110 \mathrm{~g} / \mathrm{ha}$. 
in Idaho. All plants were presumed to have been invaded uniformly while in the field. This apparent discrepancy may have been due to one or more variables encountered during the course of these experiments. First, we applied spirotetramat at a rate $25 \%$ higher in the greenhouse than in the field. Nauen et al. (14) reported that the numbers of eggs laid by aphids was reduced in a dose-dependent manner following application of spirotetramat. It is therefore possible that fewer eggs were produced in the greenhouse trial than in the field trial following applications at spirotetramat rates of 110 and $88 \mathrm{~g} / \mathrm{ha}$, respectively. Second, the commercial nematode laboratory counted all eggs present in cysts extracted from our field trials. In the greenhouse trial, we counted only the eggs that contained visually differentiated embryos of juveniles, as a measure of potentially viable eggs. Nauen et al. (14) reported that adult aphids feeding on treated plants had reduced egg fertility (producing nonviable nymphs) as well as reduced fecundity. These authors reported that many of the aphid eggs produced on treated plants failed to hatch. If reduced fertility also occurred for $H$. avenae on treated plants, the apparently higher efficacy of spirotetramat in the greenhouse than in the field, on uniformly invaded plants, could have been an artifact of the manner in which the eggs were counted in these experiments. Third, numbers of cysts were significantly lower in treated than in control plants in the greenhouse. This would not be anticipated if spirotetramat only suppressed fecundity of females and fertility of eggs. Our experiment did not determine if the insecticide may have also affected nematode ecdysis, possibly reducing the mobility and/or survival of males before they emerged from roots to fertilize the sedentary females. If copulation of multiple males with individual females was reduced, it would follow that fewer swollen white females and mature brown cysts would be produced. This mode of action is plausible in view of the findings of McKenry et al. (13), which demonstrated that nematode extraction procedures that necessitate nematode motility are the quickest to show nematicidal impact associated with spirotetramat. Fourth, much of the Idaho field soil was removed from the roots before plants were transplanted into greenhouse pots that were then filled with a soil which was not infested by $H$. avenae. It is possible that extractions of $H$. avenae directly from field soils contained a higher percentage of eggs plus juveniles derived from old cysts compared to extractions from roots from which much of the infested field soil had been removed during the transplanting process. If true, a lower residual density of old $H$. avenae cysts in the greenhouse trial would have amplified apparent differences among treatments compared to comparable numerical differences that may have occurred in the field. Therefore, while we observed a reduction in number of $H$. avenae cysts per plant when spirotetramat was applied in our greenhouse trial, it remains to be determined whether the feeding activity of $H$. avenae females is reduced by application of spirotetramat, whether a reduced mobility of $H$. avenae males suppresses copulation efficiency with females, and whether development of gravid cysts is consistently suppressed by this compound.

Grain yield and test weight were not significantly affected by up to three foliar applications of spirotetramat. Further research is required to determine if the tendency for lower yield and test weight in treated than in nontreated plots may have been an indication of phytotoxicity at the application rate, application interval, or the number of applications examined in these experiments. However, it was also clear that impaired root function occurred before the first application was applied in Idaho. In Washington, the hypersensitive reaction that results in a knotted proliferation of roots at the site of $H$. avenae invasion was first observed during the application made 20 days after the first application, but the precise time at which the abnormal root proliferation occurred was unknown. It is possible that the nematode had already invaded roots prior to the first application. Probing of root cells by juveniles occurs before feeding sites are established by developing females. Spirotetramat-enol must be ingested in sufficient quantity before insect motility, fecundity, and fertility are suppressed (14). Further testing is required to determine whether spirotetramat applied alone or as a component of an integrated control strategy (such as partially resistant cultivars, biological or chemical seed treatments, or short rotations) can increase yield of the current crop.

The commercial spirotetramat product is formulated as a suspension of a solid crystalline active ingredient that has low solubility in water. The use of a spreading and penetrating adjuvant as a tank mix with the product is important because the adjuvant facilitates retention of the droplet on the leaf surface, amplifies the area of the droplet that contacts the leaf surface, and improves the rate and efficiency of penetration of the crystalline spirotetramat through the leaf cuticle $(14,26)$. Addition of an adjuvant greatly enhances the retention of spirotetramat on treated leaves during simulated heavy rainfall events several hours after the spray is applied $(14,26)$. We treated spirotetramat solutions with the surfactant MSO and found no evidence that rainfall reduced the efficacy of spirotetramat applied to wheat, particularly in Washington where the population density of $H$. avenae was strongly suppressed even though rainfall occurred at low-intensity soon after each of the three applications. The addition of MSO apparently assured that the product performed as expected during wet as well as dry conditions at the two field sites where our experiments were performed.

Additional investigations are warranted to evaluate spirotetramat as a component of integrated management programs to reduce economic risk to small grain production in fields infested by $H$. avenae. Specifically, studies should focus on effects of rates and timing of applications, particularly with respect to the timing of juvenile invasion and development of syncytia. While our assays determined the fecundity of cysts, the fertility of eggs and mobility and survival of juveniles produced in the cysts also warrants a critical evaluation. Moreover, as shown in the Idaho experiment, we examined spirotetramat as a rescue treatment for reducing the magnitude of $H$. avenae multiplication in previously invaded roots. Since spirotetramat may be applied only after sufficient leaf area has been produced to minimize the loss of spray droplets impacting the soil surface, effects of using this compound as a companion treatment with early-season biological or chemical protectants against nematode invasion should be examined in an attempt to reduce nematode invasion in the treated crop as well as to reduce the risk of damage to subsequent susceptible crops.

\section{Acknowledgments}

The authors appreciate technical assistance by L. Bennett, D. Ball, S. Goff, and J. Gourlie (Oregon State University), and L. Ellis, C. Jackson, and T. Shelman (University of Idaho). We appreciate discounted service charges by Western Laboratories, Parma, ID, and contributions by growers who donated land and crop management for the field trials; D. and B. Daw, St. Anthony, ID, and R. and L. Stueckle, Palouse, WA. We also gratefully acknowledge funding from Bayer CropScience, Idaho Wheat Commission, Oregon Wheat Commission, Washington Wheat Commission, USDA-Agricultural Research Service, and the Agricultural Experiment Stations of Idaho and Oregon.

\section{Literature Cited}

1. Baldwin, J. G., and Mundo-Ocampo, M. 1991. Heteroderinae, cyst- and non-cyst-forming nematodes. Pages 275-362 in: Manual of Agricultural Nematology. W. R. Nickle, ed. Marcel Dekker, New York.

2. Brown, R. H., and Kerry, B. R., eds. 1987. Principles and Practice of Nematode Control in Crops. Academic Press, Sydney, Australia.

3. Cantoni, A., de Maeyer, L., Izquierdo Casas, J., Niebes, J.-F., Peeters, D., Roffen, S., Silva, J., and Villalobos, A. 2008. Development of Movento ${ }^{\circledR}$ on key pests and crops in European countries. Bayer CropSci. J. 61:349-376.

4. Cook, R. J., and Veseth, R. J. 1991. Wheat Health Management. American Phytopathological Society, St. Paul, MN.

5. Fushtey, S. G. 1965. The oat cyst nematode, Heterodera avenae Wollenweber, on corn, Zea mays, in Ontario. Can. Plant Dis. Surv. 45:105-106.

6. Hajihasani, A., Tanha Maafi, Z., and Hajihasani, M. 2010. The life cycle of Heterodera filipjevi in winter wheat under microplot conditions in Iran. Nematol. Mediterr. 38:53-58.

7. Handoo, Z. A. 2002. A key and compendium to species of the Heterodera avenae Group (Nematodoa: Heteroderidae). J. Nematol. 34:250-262.

8. Ingham, R. E. 1994. Nematodes. Pages 459-490 in: Methods of Soil Analysis, Part 2. Microbiological and Biochemical Properties. R. W. Weaver, ed. American Society of Agronomy, Madison, WI.

9. Jensen, H. J., Eshtiaghi, H., Koepsell, P. A., and Goetze, N. 1975. The oat cyst nematode, Heterodera avenae, occurs in oats in Oregon. Plant Dis. Rep. 59:1-3. 
10. Kühnhold, J., Kleuken, A. M., de Maeyer, L., van Waetermeulen, X., Brück, E., and Elbert, A. 2008. Movento ${ }^{\circledR}$, an innovative solution for sucking insect pest control in agriculture: Field performance in fruits and vegetables. Bayer CropSci. J. 61:279-306.

11. Lozano, F., Kemper, K., and Tundisi, H. 2008. Field development of Movento ${ }^{\circledR}$ Plus for sucking insect control in Brazil. Bayer CropSci. J. 61:329-348.

12. McKenry, M., Buzo, T., and Kaku, S. 2011. Performance of spirotetramat foliar on Pratylenchus vulnus infected Juglans spp. (Abstr.) J. Nematol. In press.

13. McKenry, M., Kaku, S., and Buzo, T. 2009. Evaluation of Movento ${ }^{\mathrm{TM}}$ (spirotetramat) for efficacy against nematodes infesting perennial crops. (Abstr.) J. Nematol. 41:355.

14. Nauen, R., Reckmann, U., Thomzik, J., and Thielert, W. 2008. Biological profile of spirotetramat (Movento ${ }^{\circledR}$ ) - a new two-way systemic (ambimobile) insecticide against sucking pest species. Bayer CropSci. J. 61:245278 .

15. Riley, I. T., Nicol, J. M., and Dababat, A. A., eds. 2009. Cereal Cyst Nematodes: Status, Research and Outlook. CIMMYT, Ankara, Turkey.

16. Rivoal, R., and Cook, R. 1993. Nematode pests of cereals. Pages 259-303 in: Plant Parasitic Nematodes in Temperate Agriculture. K. Evans, D. L. Trudgill, and J. M. Webster, eds. CAB Int., Wallingford, UK.

17. Safferling, M., ed. 2008. Spirotetramat: The first phloem-mobile and fully systemic insecticide. Bayer CropSci. J. 61(2).

18. Smiley, R. W. 2009. Occurrence, distribution and control of Heterodera avenae and $H$. filipjevi in the western USA. Pages 35-40 in: Cereal Cyst Nematodes: Status, Research and Outlook. I. T. Riley, J. M. Nicol, and A. A. Dababat, eds. CIMMYT, Ankara, Turkey.

19. Smiley, R. W. 2010. Root-lesion nematodes reduce yield of intolerant wheat and barley. Agron. J. 101:1322-1335.

20. Smiley, R. W., Ingham, R. E., Uddin, W., and Cook, G. H. 1994. Crop sequences for managing cereal cyst nematode and fungal populations of win- ter wheat. Plant Dis. 78:1142-1149.

21. Smiley, R. W., and Nicol, J. M. 2009. Nematodes which challenge global wheat production. Pages 171-187 in: Wheat Science and Trade. B. F. Carver, ed. Wiley-Blackwell, Ames, IA.

22. Smiley, R. W., Whittaker, R. G., Gourlie, J. A., and Easley, S. A. 2006 Geocenamus brevidens associated with reduced yield of no-till annual spring wheat in Oregon. Plant Dis. 90:885-890.

23. Smiley, R. W., Whittaker, R. G., Gourlie, J. A., Easley, S. A., and Ingham, R. E. 2005. Plant-parasitic nematodes associated with reduced wheat yield in Oregon: Heterodera avenae. J. Nematol. 37:297-307.

24. Smiley, R. W., and Yan, G. P. 2010. Cereal Cyst Nematodes: Biology and management in Pacific Northwest wheat, barley and oat crops. PNW Extension Bulletin 620, Oregon State University, Corvallis, OR.

25. Smiley, R. W., Yan, G. P., and Pinkerton, J. N. 2011. Resistance of wheat, barley and oat to Heterodera avenae in the Pacific Northwest USA. Nematology 13:539-552.

26. Vermeer, R., and Baur, P. 2008. Movento ${ }^{\circledR}$ Product development: Custommade formulations for an exceptional active ingredient. Bayer CropSci. J. 61:141-158.

27. Yan, G. P., and Smiley, R. W. 2009. Discovery of Heterodera filipjevi on wheat in the USA. Pages 94-99 in: Cereal Cyst Nematodes: Status, Research and Outlook. I. T. Riley, J. M. Nicol, and A. A. Dababat, eds. CIMMYT, Ankara, Turkey.

28. Yan, G. P., and Smiley, R. W. 2010. Distinguishing Heterodera filipjevi and $H$. avenae using polymerase chain reaction-restriction fragment length polymorphism and cyst morphology. Phytopathology 100:216-224.

29. Yan, G. P., Smiley, R. W., Okubara, P. A., Skantar, A., Easley, S. A., Sheedy, J. G., and Thompson, A. L. 2008. Detection and discrimination of Pratylenchus neglectus and P. thornei in DNA extracts from soil. Plant Dis. 92:1480 1487.

30. Zadoks, J. C., Chang, T. T., and Konzak, C. F. 1974. A decimal code for the growth stages of cereals. Weed Res. 14:415-421. 